\title{
Stuburo stabilizavimo pratimų ir smūginès bangos terapijos efektyvumas, esant juosmeninès srities radikulopatijai
}

\section{J. Bubelis}

Šiauliu valstybine kolegija, Sveikatos priežiūros fakultetas, Reabilitacijos katedra

\author{
Adresas: \\ Justinas Bubelis \\ Šiauliu valstybine kolegija, \\ Sveikatos priežiūros fakultetas, \\ Reabilitacijos katedra \\ M. K. Čiurlionio g. 16 a, \\ LT-76228 Šiauliai \\ El.paštasj.bubelis@svako.lt
}

\begin{abstract}
Santrauka. İvadas. Radikulopatija - tai juosmeninès stuburo dalies nervų šaknelių pažeidimas, išsivystantis dẻl nervinès šaknelès spaudimo ir dirginimo. Esant juosmeninei radikulopatijai, pasireiškia daug įvairių simptomų, tarp kurių dažniausi: skausmas apatinėje nugaros dalyje ir skausmo plitimas ị apatines galūnes, raumenų silpnumas, propriorecepcijos ir posturalinès kontrolès sutrikimai, neigiamai veikiantys asmens kasdieninę veiklą ir gyvenimo kokybę, kas lemia darbingo amžiaus žmonių darbo našumo sumažėjimą, negalios vystymąsi. Nustatyta, kad kineziterapijos metu taikomi fiziniai pratimai ir fizioterapijos priemonès gali sumažinti skausmą, pagerinti pusiausvyrą ir jos valdymą.

Tiriamieji ir tyrimo metodai. Tyrime dalyvavo 40 asmenu ( 22 moterys ir 18 vyrų), kuriems diagnozuota juosmeninė radikulopatija. Tiriamieji atsitiktiniu atrankos būdu suskirstyti ị dvi grupes po 20 tiriamujų kiekvienoje grupejje, kur I grupei taikytas stuburo stabilizavimo pratimų ciklas, o II grupei - stuburo stabilizavimo pratimų ir smūginès bangos terapijos užsièmimų ciklas. Skausmui vertinti pasirinkta vizualinė skausmo analogijos skalė (VAS) (angl. Visual Analogue Scale), dinaminiam stabilumui vertinti - modifikuotas žvaigždès dinaminio stabilumo Y testas, liemens raumenų statinei ištvermei vertinti - du testai: pilvo raumenų statinės jẻgos ištvermès ir nugaros raumenų statinès jẻgos ištvermès. Duomenys apdoroti atlikus matematinę statistinę analizę.
\end{abstract}

Rezultatai. Skausmas po taikytų skirtingų kineziterapijos programų sumažejo abiejose tiriamuju grupèse. I grupès tiriamiesiems skausmas sumažèjo nuo $5,77 \pm 1,88$ balo iki $3,85 \pm 1,25$ balo, II grupès tiriamiesiems skausmas sumažèjo nuo $5,40 \pm 1,24$ balo iki $2,55 \pm 1,05$ balo. Vertinant tiriamujų dinaminio stabilumo pokyčius po 4 savaičių kineziterapijos užsièmimų ciklo, nustatytas dinaminio stabilumo pagerẻjimas abiejų grupių tiriamiesiems, tačiau didesni pokyčiai fiksuoti II grupès tiriamiesiems, kuriems taikytas stuburo stabilizavimo ir smūginės bangos terapijos užsièmimų ciklas. Taip pat prieš ir po kineziterapijos užsièmimų ciklo buvo apskaičiuotas kombinuoto rezultato koeficientas, kuris rodo, ar yra tikimybė patirti traumas dèl pablogejusio dinaminio stabilumo ir jo valdymo. Prieš kineziterapijos užsièmimų ciklą I grupès tiriamujų kombinuoto rezultato koeficientas buvo 92,3\%, o II grupès tiriamujų - 92,9\%. Po 4 savaičių taikytų užsièmimų nustatytas abiejų grupių tiriamujjų kombinuoto rezultato koeficiento padidejimas: I grupėje - 2,8 \%, o II grupẻje - 3,5\%. Po užsiemimų ciklo I grupès tiriamujjų kombinuoto rezultato koeficientas siekė $95,1 \%$, II grupès tiriamujų - 96,4\%. Nustatyta, kad, jeigu kombinuotas rezultatas yra mažiau kaip $94 \%$, yra padidejjusi tikimybẻ patirti traumas. Taigi prieš kineziterapijos užsiẻmimų ciklą asmenims, kuriems nustatyta radikulopatija ir patiriantiems vidutinio intensyvumo skausmą, yra tikimybẻ dẻl dinaminio stabilumo pakitimo patirti apatinių galūnių traumas. Po užsièmimu ciklo kombinuotas rezultatas pasiekė daugiau kaip $94 \%$, taigi tikimybė patirti traumas sumažejo $(p=0,032)$. Taip pat po kineziterapijos fiksuotas pilvo ir nugaros raumenų statinès ištvermès jëgos pagerèjimas abiejose tiriamụjų grupėse, tačiau, lyginant grupes, didesnis liemens raumenų statinès jëgos ištvermès pokytis $(p=0,029)$ fiksuotas II grupès tiriamiesiems, kuriems taikytas stuburo stabilizavimo ir smūginès bangos terapijos užsièmimų ciklas.

Išvados. 1. Po kineziterapijos užsièmimų ciklo sumažèjo abiejų grupių tiriamųjų jaučiamas skausmas, kuris kito nuo vidutinio (5-6 balų) iki silpno (3-2 balų). Lyginant abi grupes, didesnis skausmo sumažèjimas stebètas II grupès tiriamiesiems, kuriems taikytas stuburo stabilizavimo ir smūginès bangos terapijos ciklas. 2. Po kineziterapijos užsièmimu ciklo abiejų grupių tiriamiesiems padidejjo pilvo ir nugaros raumenų statinè jẻgos ištvermè.

(C) Neurologijos seminarai, 2018. Open Access. This article is distributed under the terms of the Creative Commons Attribution 4.0 International License CC-BY 4.0 (http://creativecommons.org/licenses/by/4.0/), which permits unrestricted use, distribution, and reproduction in any medium, provided you give appropriate credit to the original author(s) and the source, provide a link to the Creative Commons license, and indicate if changes were made. 
Didesnis teigiamas pokytis fiksuotas II grupès tiriamiesiems. 3. Po kineziterapijos užsièmimų ciklo pagerèjo tiriamujų dinaminis stabilumas ir sumažèjo tikimybė patirti traumas. 4. Lyginant abi grupes, galima teigti, kad didesnị teigiamą poveikị skausmui, raumenų jègos ištvermei, dinaminiam stabilumui ir jo valdymui turejo taikomas stuburo stabilizavimo pratimų programos ir smūginès bangos terapijos ciklas.

Raktažodžiai: juosmeninè radikulopatija, stuburo stabilizavimo pratimai, smūginės bangos terapija, skausmas.

\section{IVADAS}

Juosmeninè radikulopatija paveikia vis didesnị darbingo amžiaus žmonių skaičių, kas lemia darbingumo ir darbo našumo sumažėjimą. Vienas iš pagrindinių juosmeninès radikulopatijos požymių ir simptomų - apatinès nugaros dalies skausmas [1]. Remiantis naujausiais pasaulinio lygio atliktų tyrimų duomenimis, nustatyta, kad nugaros skausmas yra labiausiai paplitusi negalia visame pasaulyje [2]. $2017 \mathrm{~m}$. Hekmatfard su kolegomis savo atliktame tyrime nurodè, kad nugaros skausmus patiria apie 70-80\% populiacijos [3].

Juosmeninès radikulopatijos patofiziologinis mechanizmas - tai nervinių šaknelių pažeidimas, kurị gali sukelti tarpslankstelinio disko išvarža, spondiliozè, degeneracinès stuburo ligos [4], rečiau traumos, stuburo raiščiu pakitimai, kaulinès išaugos, navikai, infekcijos ir kitos struktūrinès stuburo patologijos [5]. $2012 \mathrm{~m}$. Schoenfeld su kolegomis publikuotame straipsnyje teigè, kad galima išskirti modifikuojamus ir nemodifikuojamus rizikos veiksnius, kurie apima demografinius rodiklius, gyvenimo būdą, profesinius, fizinius, psichologinius ir psichosocialinius veiksnius [6]. $2017 \mathrm{~m}$. Kresal su bendraautoriais pateikè išvadą, kad amžius, moteriška lytis, išsilavinimo lygis, nutukimas, rūkymas, miego sutrikimai, ilgas sėdimas darbas, pasikartojančių nuolatinių judesių seka, ilgalaikẻ statinė laikysena taip pat sąlygoja juosmeninès radikulopatijos išsivystymą [7].

Esant juosmeninei radikulopatijai, dažniausiai nurodomi šie požymiai: skausmas [8], pilvo ir nugaros raumenų jègos ir ištvermès sumažėjimas [9], šilumos hiperalgezija, dinaminè arba mechaninė alodinija ir hiperalgezija L5 ar S1 dermatomose, kurios sutampa su nervinès šaknelès inervacijos zona [10]. Taip pat pastebèta, kad dèl stuburą stabilizuojančių raumenų jègos disbalanso gali padidèti kojų traumų rizika [11]. Juosmeninès radikulopatijos metu išsivystęs skausmas ir kiti požymiai bei simptomai sutrikdo ịprastą žmogaus gyvenimo ritmą, blogina jo darbinę veiklą ir gyvenimo kokybę. Pabréžtina ir tai, kad ilgai trunkantis skausmas gali sąlygoti depresijos, nerimo ar miego sutrikimų pasireiškimą, kurie vėlgi blogina gyvenimo kokybę [12].

Dèl juosmeninès radikulopatijos polietiologijos ir simptomų gausos būtina taikyti įvairias gydymo ir skausmo valdymo strategijas. Šios ligos gydymas turi būti kompleksinis, derinant įvairius gydymo metodus. Viso pasaulio mokslininkai nuolat stengiasi tobulinti jau esamus kineziterapijos metodus ir atrasti naujus efektyvesnius juosme- ninès radikulopatijos sukeliamų skausmų mažinimo būdus, taikant biopsichosocialinị reabilitacijos modeli [13]. Mokslinè studija, nagrinejjanti stuburo stabilizavimo pratimų poveikį nugaros skausmui, raumenų jègos statinei ištvermei, irodè, kad po 8 savaičių trukusio tyrimo statistiškai reikšmingai $(\mathrm{p}<0,05)$ sumažejo skausmas ir padidejo raumenų jėgos statinè ištvermé [14]. Taip pat teigiamas poveikis skausmo mažinimui nustatytas taikant smūginę bangos terapiją, kuri, kaip teigia mokslininkai, yra susijusi su angiogenezès skatinimu, perfuzijos didejjimu išeminiuose audiniuose, uždegimo proceso mažinimu, ląstelių diferencijavimo intensyvinimu, pagreitėjusiu žaizdų giji$\mathrm{mu}$ ir skausmo signalo perdavimo pokyčiais [15].

Išanalizavus daugelio užsienio autorių atliktų mokslinių studijų publikacijas, galima teigti, kad stuburo stabilizavimo pratimai ir smūginès bangos terapijos užsièmimai turi teigiamą poveikị juosmeninès radikulopatijos metu išsivysčiusio skausmo mažinimui, raumenų jejgos statinès ištvermès didinimui ir dinaminio stabilumo užtikrinimui.

\section{DARBO TIKSLAS}

İvertinti stuburo stabilizavimo pratimų ir smūginès bangos terapijos efektyvumą, esant juosmeninei radikulopatijai.

\section{TIRIAMIEJI IR TYRIMO METODAI}

Tiriamieji. Tyrime dalyvavo 40 asmenų (22 moterys ir 18 vyrų), kuriems nustatyta juosmeninè radikulopatija. Tiriamieji pasirinkti pagal įtraukimo kriterijus: amžius - nuo 20 iki 55 m. (darbingo amžiaus žmonès); gydytojo medicininè diagnozė - juosmeninė radikulopatija; skausmas nuo lengvo iki vidutinio, t. y. remiantis VAS, 2-7 balų is 10; skausmo trukmė - ilgesnè nei 3 mèn.; gebejjimas suprasti tyrimo metu naudojamus testus bei klausimynus ir atsakyti ị juos; savanoriškas dalyvavimas tyrime, patvir-

Lentelè. Tiriamụjų amžiaus, kūno masès, ūgio ir ligos trukmès charakteristikos (vid. \pm SD)

\begin{tabular}{|l|c|c||}
\hline \multirow{2}{*}{ Charakteristikos } & \multicolumn{2}{|c|}{ Tiriamieji } \\
\cline { 2 - 3 } & I grupé & II grupe் \\
\hline Amžius (m.) & $45,49 \pm 7,43$ & $46,39 \pm 6,61$ \\
\hline Ūgis $(\mathrm{cm})$ & $1,67 \pm 0,82$ & $1,69 \pm 0,96$ \\
\hline Svoris $(\mathrm{kg})$ & $68,38 \pm 10,12$ & $71,21 \pm 8,85$ \\
\hline
\end{tabular}



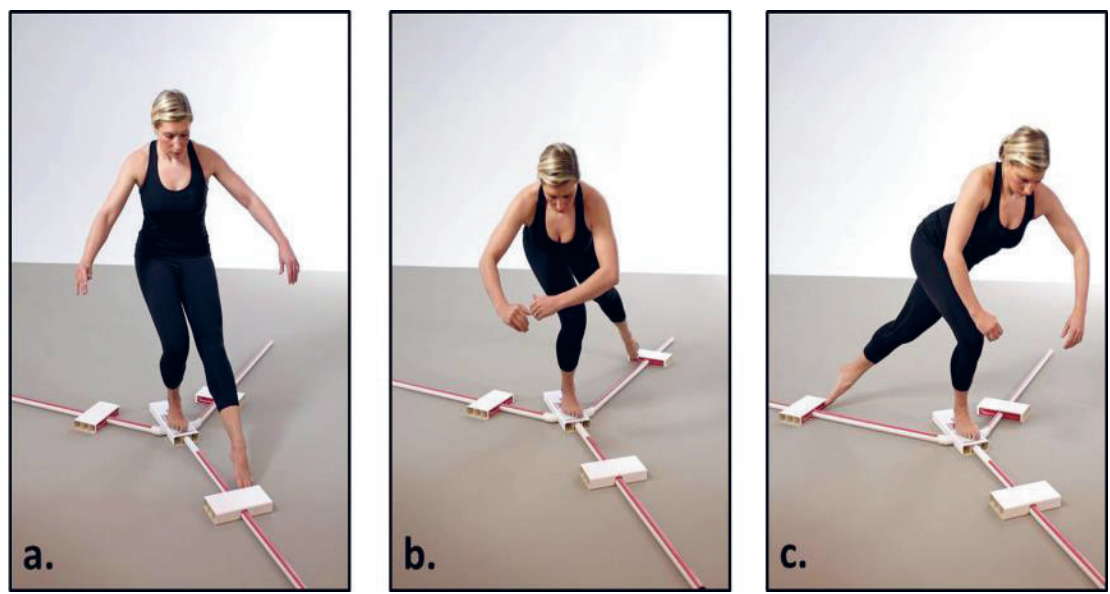

1 pav. Dinaminio stabilumo $\mathbf{Y}$ pusiausvyros testo atlikimas

a - siekimas pirmyn, b - siekimas posteromedialine kryptimi, c - siekimas posterolateraline kryptimi

tintas parašu informuoto asmens sutikimo formoje. Tiriamujų amžiaus, ūgio ir svorio charakteristikos pavaizduotos lentelèje.

Tyrimas buvo atliktas Všı̨ Šiaulių reabilitacijos centre. Tiriamieji atsitiktiniu atrankos būdu buvo suskirstyti ị 2 grupes: I grupei $(n=20)$ kineziterapijos procedūrų metu buvo taikomi stuburo stabilizavimo pratimai, II grupei $(\mathrm{n}=20)$ kineziterapijos procedūrų metu buvo taikomas stuburo stabilizavimo ir smūginès bangos terapijos užsièmimų ciklas. Pirmiausia buvo atliekamas pirminis testavimas, po kurio sekẻ 4 savaičių kineziterapijos užsiėmimų kursas (3 kartus per savaitę nuo 35 iki 45 minučių) ir galutinis testavimas po kineziterapijos.

Tyrimo metodai. Tyrimo metu skausmui vertinti buvo pasirinkta vizualine skausmo vertinimo skale (VAS), dinaminiam stabilumui vertinti ir traumų rizikai vertinti - dinaminio stabilumo $Y$ testas, kur pagal formulę* yra apskaičiuojamas kombinuoto rezultato koeficientas, padedantis nustatyti traumų riziką. Liemens raumenų statinei ištvermei vertinti pasirinkti pilvo ir nugaros raumenu ištvermés jegos vertinimo testai.

Dinaminiam stabilumui vertinti pasirinktas modifikuotas žvaigždès dinaminio stabilumo Y testas. Stovėdamas ant vienos kojos, tiriamasis laisva galūne siekia pirmyn, atgal ị šoną (posterolateraline) ir atgal ị vidų (posteromedialine) stovimosios kojos atžvilgiu. Tiriamasis turi stovèti viena koja ant platformos, kad distaliniai pirštų galai būtų ant raudonos starto linijos. Rekomenduojama Y pusiausvyros testo atlikimo tvarka: 3 bandymai, stovint ant dešinės kojos, siekti pirmyn, tada 3 bandymai, stovint ant kairès kojos, siekti laisva galūne pirmyn. Tokia tvarka atliekami bandymai atgal ị šoną ir atgal ị vidų kryptimis. Tiriamasis stovi ant platformos, pirštų galais liesdamas raudoną pradžios liniją, ir laisva galūne stumia siekimo žymeklị testuojamaja kryptimi. Pasiektas atstumas matuojamas ties žymeklio kraštu, ị kurị remiasi siekiančios tolyn kojos pirštai. Geriausias bandymas, kuris naudojamas statistinei analizei.
Liemens raumenų statinei ištvermei pasirinkti pilvo ir nugaros raumenų ištvermès jègos vertinimo testai.

Pilvo raumenu statinès jegos ištvermès testas yra skirtas įvertinti statinę pilvo raumenų jègos ištvermę. Testo atlikimo metodika: tiriamasis guli ant medicininès kušetès ant nugaros, kelių sąnariai sulenkti 90 laipsnių, o klubo sąnariai - 45 laipsnių kampu, rankos atpalaiduotos ir padètos prie šonų. Testo metu tiriamasis atlieka prisilenkimą, keldamas galvą, pečius, mentes ir krūtinès ląstą, rankomis artėdamas kelių link. Rankų pirštų galais liečiama viršutinė kelių girnelių dalis. Tokioje padètyje stengiamasi išsilaikyti kiek ịmanoma ilgiau. Testo laikas fiksuojamas chronometru. Laikas stabdomas tada, kai: tiriamojo pirštų galai praranda kontaktą su girnele, mentès pasiekia medicininę kušetę, tiriamasis atsisako tęsti tyrimą arba atsiranda aštrus skausmas.

Nugaros raumenų statinès jègos ištvermès testas yra skirtas įvertinti tiesiamųjų nugaros raumenų statinę jègos ištvermę. Testo atlikimo metodika: tiriamasis guli ant medicininès kušetės ant pilvo. Atliekamas liemens tiesimosi judesys: krūtinkaulis nuo kušetės keliamas per plaštaką, rankos išlaikomos priglaustos prie liemens Tiriamasis tokią padètị išlaiko kiek ịmanoma ilgiau. Testo laikas fiksuojamas chronometru ir stabdomas tada, kai: tiriamasis paliečia medicininę kušetę krūtine, atsisako tęsti tyrimą arba atsiranda aštrejjantis skausmas.

\section{Statistinis duomenų apdorojimas}

Duomenys statistiškai apdoroti naudojant SPSS 21.0. for Windows ir Microsoft Office Excel 2010 statistinius paketus. Buvo nustatyti nominalinių kintamųjų dažnumas ir pagrindinès statistinės intervalinių rodiklių charakteristikos: mažiausia ir didžiausia reikšmès, vidurkiai, standartiniai nuokrypiai. Priklausomų imčių rodikliams lyginti naudoti Stjudento $t$ kriterijus (T-test), chi kvadrato kriterijus bei Wilcoxon ir Kruscal-Wallis testai. Statistiškai patikimi skirtumai buvo fiksuojami, kai $\mathrm{p}<0,05$.

\footnotetext{
*Kombinuotas rezultatas $=\frac{\text { priekinė pusė }(\mathrm{cm})+\text { vidinė pusė }(\mathrm{cm})+\text { išorinė pusė }(\mathrm{cm})}{3 \times \text { kojos ilgis }(\mathrm{cm})} \times 100$
} 


\section{REZULTATAI}

Kadangi vis ieškoma naujų kineziterapijos metodų, kurie būtų efektyviausi juosmeninès radikulopatijos sukeltam skausmui ir sumažějusiai raumenų jègos ištvermei mažinti, o mokslinejje literatūroje stebimi atskirų kineziterapijos metodų poveikių tyrimai, nuspręsta šio tyrimo metu taikyti du tarpusavyje derinamus metodus, t. y. stuburo stabilizavimo pratimus ir smūginès bangos terapiją. Išanalizavę ir apibendrinę tyrimo rezultatus, galime teigti, kad tiek stuburo stabilizavimo pratimai, tiek stuburo stabilizavimo pratimai kartu su smūginès bangos terapija turi teigiamą poveikį mažinant skausmą, didinant raumenų jẻgos ištvermę ir dinaminị stabilumą.

Nustatyta, kad I grupès tiriamujju jaučiamo skausmo balo vidurkis prieš kineziterapijos užsièmimų ciklą buvo $5,77 \pm 1,88$ balo, II grupejje $-5,40 \pm 1,24$ balo. Po užsièmimų ciklo skausmo intensyvumo vidurkis I grupeje sumažèjo ir siekẻ 3,85 $\pm 1,25$ balo, II grupejje skausmo intensyvumo vidurkis taip pat sumažejo ir siekè $2,55 \pm 1,05$ balo. Taigi skausmo intensyvumas abiejose tiriamosiose grupèse prieš ir po užsiẻmimų statistiškai reikšmingai sumažejo $(\mathrm{p}<0,05)$. I grupės tiriamiesiems, kuriems taikytas tik stuburo stabilizavimo pratimu ciklas, skausmo intensyvumas sumažėjo 33,3 \% (p = 0,023), o II grupejje, kuriai taikytas stuburo stabilizavimo pratimų ciklas ir smūginè bangos terapija, skausmo intensyvumas sumažèjo 52,8 \% $(\mathrm{p}=0,039)(2$ pav. $)$.

Tyrimo pradžioje įvertinus I ir II grupių tiriamujų dinaminio stabilumo testavimo metu indikatoriaus nustumtą atstumą anteriorine kryptimi ir palyginus gautus grupių rezultatus, nustatyta, kad I grupès tiriamieji indikatorių prieš kineziterapijos užsièmimų ciklą nustūmè $66,4 \pm 1,41 \mathrm{~cm}$, o II grupès tiriamieji - 66,2 $\pm 1,38 \mathrm{~cm}$. Po 4 savaičiu taikyto kineziterapijos užsiėmimų ciklo pastebėta, kad abiejų grupių tiriamụjų indikatoriaus nustūmimo anteriorine kryptimi rezultatai padidejo: I grupeje rezultatas sieke $68,19 \pm 1,87 \mathrm{~cm}$, o II grupejje - 68,09 $\pm 1,92 \mathrm{~cm}$ (3 pav.).

Vertinant tiriamujų dinamini stabilumą, modifikuotu Y žvaigždès nuokrypio testu yra vertinamos 3 skirtingos indikatoriaus stūmimo kryptys. 4 paveiksle pavaizduota antroji kryptis - posteromedialinė. I grupés tiriamujų nustumtas atstumas prieš stuburo stabilizavimo pratimų programos taikymą buvo $101,3 \pm 7,6 \mathrm{~cm}$, po 4 savaičių taikyto užsièmimų ciklo indikatoriaus nustūmimas posteromedialine kryptimi padidejo ir siekè 104,3 $\pm 6,1 \mathrm{~cm}(\mathrm{p}=0,022)$. II grupès tiriamieji prieš užsièmimų ciklą indikatoriu posteromedialine kryptimi nustūmè $100,7 \pm 8,4 \mathrm{~cm}$, po $4 \mathrm{sa}$ vaičiu II grupès tiriamųjų nustumtas atstumas posteromedialine kryptimi statistiškai reikšmingai padidèjo $(p=0,015)$ ir siekè $105,3 \pm 3,6 \mathrm{~cm}$. Lyginant grupių rezultatus, didesnis teigiamas statistiškai reikšmingas $(\mathrm{p}=0,021)$ poveikis nustatytas II grupès tiriamiesiems, $\mathrm{ku}-$ riems taikytas stuburo stabilizavimo ir smūginès bangos terapijos užsièmimų ciklas.

Tyrimo pradžioje ir pabaigoje buvo įvertintas I ir II grupių tiriamujų indikatoriaus nustumtas atstumas po-

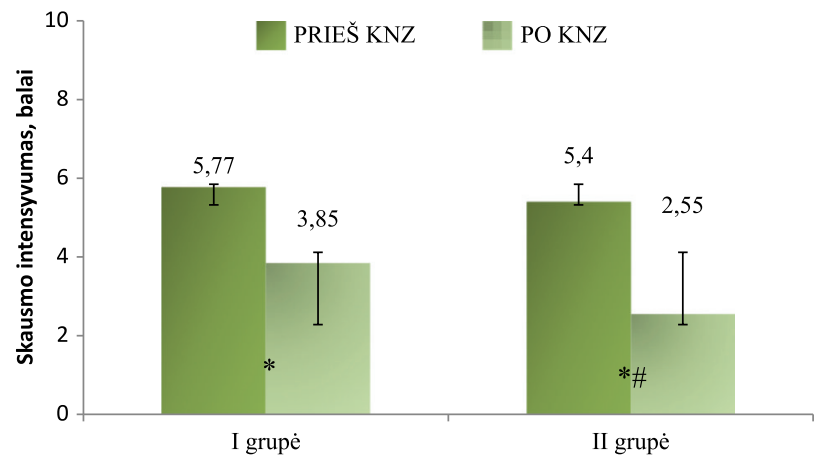

2 pav. I ir II grupių tiriamųjų skausmo intensyvumo vertinimas prieš ir po kineziterapijos užsièmimu ciklo

Pastaba: * $\mathrm{p}<0,05$, lyginant grupių rezultatus prieš KNZ ir po KNZ užsièmimų, \# $\mathrm{p}<0,05$, lyginant grupių rezultatus po KNZ užsièmimų.

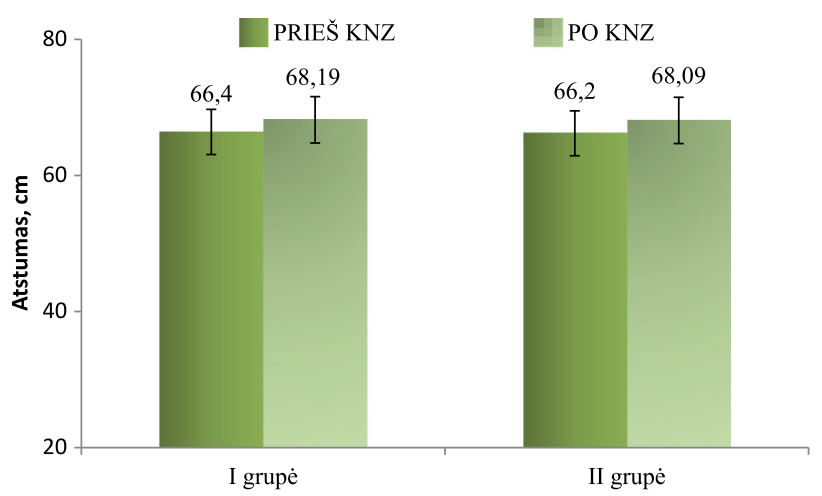

3 pav. I ir II grupių tiriamuju indikatoriaus nustūmimo anteriorine kryptimi atstumo vidurkiai prieš ir po kineziterapijos užsiėmimu ciklo

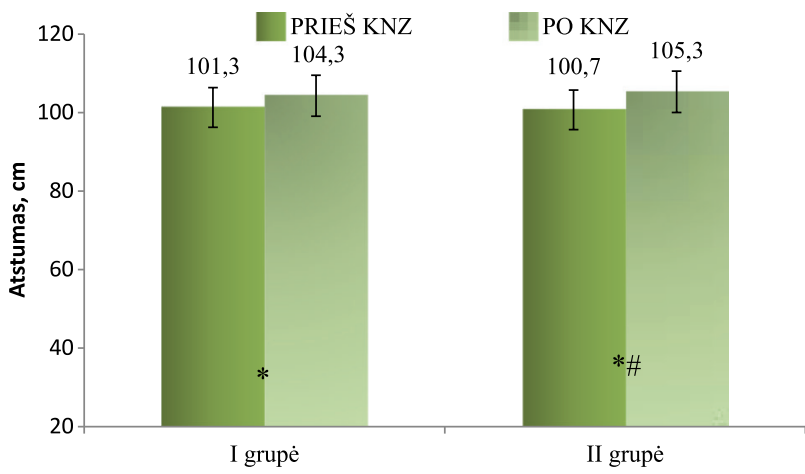

4 pav. I ir II grupių tiriamujų̨ indikatoriaus nustūmimo posteromedialine kryptimi atstumo vidurkiai prieš ir po kineziterapijos užsièmimų ciklo

Pastaba: ${ }^{*} \mathrm{p}<0,05$, lyginant grupių rezultatus prieš $\mathrm{KNZ}$ ir po $\mathrm{KNZ}$ užsièmimų, \#p $<0,05$, lyginant grupių rezultatus po KNZ užsièmimų.

sterolateraline kryptimi. I grupès tiriamieji prieš kineziterapijos užsiemmimus indikatorių posterolateraline kryptimi nustūmė $94,2 \pm 2,25 \mathrm{~cm}$, o II grupès tiriamieji $94,7 \pm 1,89 \mathrm{~cm}$. Po 4 savaičių užsièmimo ciklo abiejų grupių tiriamujų nustumto atstumo posterolateraline kryptimi rezultatas padidejo: I grupejje siekè $97,4 \pm 2,23 \mathrm{~cm}$ $(\mathrm{p}=0,028)$, o II grupéje $-98,09 \pm 6,4 \mathrm{~cm}(\mathrm{p}=0,031)$. Lyginant rezultatus prieš ir po 4 savaičių trukusio kineziterapijos užsièmimų ciklo, stebimi statistiškai reikšmingi poky- 


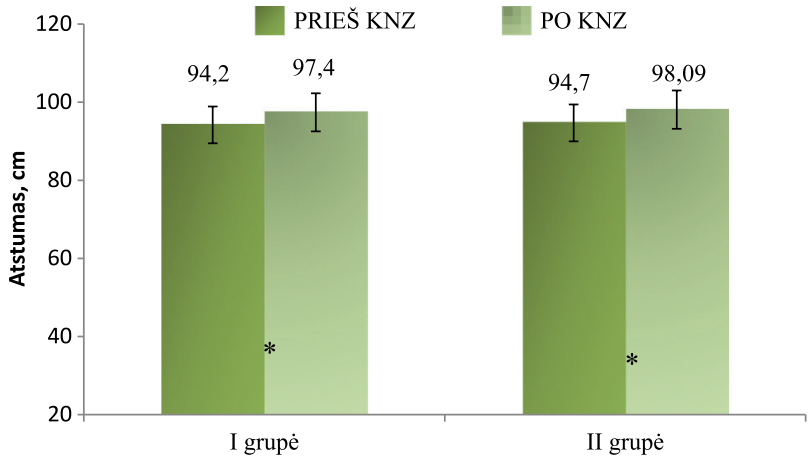

5 pav. I ir II grupių tiriamųjų indikatoriaus nustūmimo posterolateraline kryptimi atstumo vidurkiai prieš ir po kineziterapijos užsiėmimų ciklo

Pastaba: ${ }^{*} \mathrm{p}<0,05$, lyginant grupių rezultatus prieš KNZ ir po KNZ užsiëmimų.

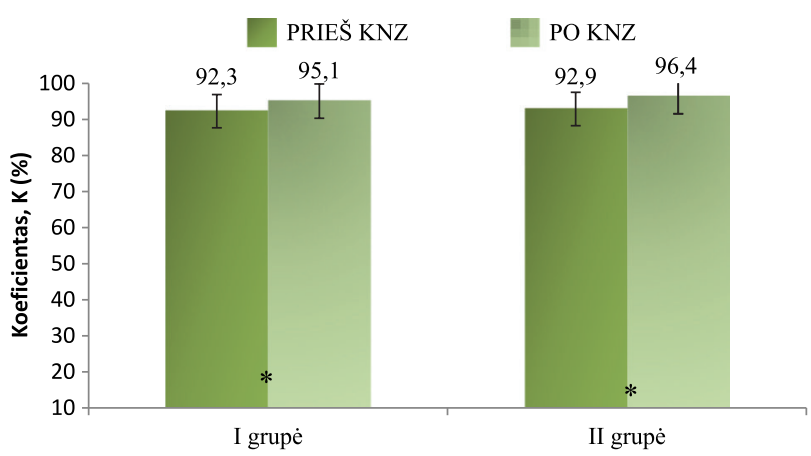

6 pav. I ir II grupiu tiriamuju kombinuoto rezultato koeficiento vidurkiai prieš ir po kineziterapijos užsièmimų ciklo Pastaba: ${ }^{*} \mathrm{p}<0,05$, lyginant grupių rezultatus prieš KNZ ir po KNZ užsiëmimų.

čiai, tačiau, lyginant grupių rezultatus, statistiškai reikšmingo pokyčio nefiksuota (5 pav.).

Prieš kineziterapijos užsièmimų ciklą I grupès tiriamųjų kombinuoto rezultato koeficientas buvo $92,3 \%$, o II grupès tiriamųjų - 92,9\%. Po 4 savaičių taikytų skirtingų užsièmimų nustatytas abiejų grupių tiriamųjų kombinuoto rezultato koeficiento padidejjimas: I grupèje - iki $95,1 \%$, o II grupeje - iki 96,4 \%. Taigi prieš kineziterapijos užsièmimų ciklą asmenims, kuriems nustatyta radikulopatija ir patiriantiems vidutinio intensyvumo skausmą, yra tikimybẻ dèl dinaminio stabilumo pakitimo patirti apatinių galūnių traumas. Po užsièmimų ciklo kombinuotas rezultatas pasiekė daugiau kaip $94 \%$. Tai rodo, kad tikimybė patirti traumas sumažèjo $(p=0,001)$. Lyginant abiejų grupių rezultatus, nustatyta, kad II grupès tiriamiesiems, kuriems taikytas stuburo stabilizavimo ir smūginès bangos terapijos užsiėmimų ciklas, kombinuotas rezultatas padidejjo daugiau, tačiau šis pokytis, lyginant su I grupe, nèra statistiškai reikšmingas $(p=0,06)(6$ pav.).

Prieš kineziterapijos užsiemmimų ciklą buvo įvertinta I ir II grupių tiriamujų statinè pilvo raumenų jègos ištvermè. Nustatyta, kad I grupès tiriamuju pirminio testavimo metu statinė pilvo raumenų jègos ištvermé buvo $15,9 \pm 2,9$ sekundès. Po 4 savaičių kineziterapijos užsièmimų ciklo šios grupès tiriamujų pilvo raumenų statinè ištvermė pagerèjo

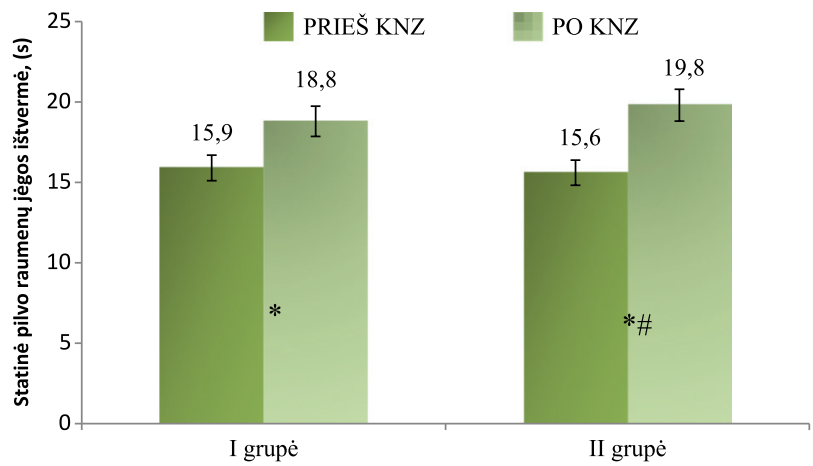

7 pav. I ir II grupių tiriamujų statinės pilvo raumenų jẻgos ištvermès vertinimas prieš ir po kineziterapijos užsiẻmimų ciklo Pastaba: ${ }^{*} \mathrm{p}<0,05$, lyginant grupių rezultatus prieš KNZ ir po KNZ užsièmimų, $\# \mathrm{p}<0,05$, lyginant grupių rezultatus po KNZ užsiẻmimų.

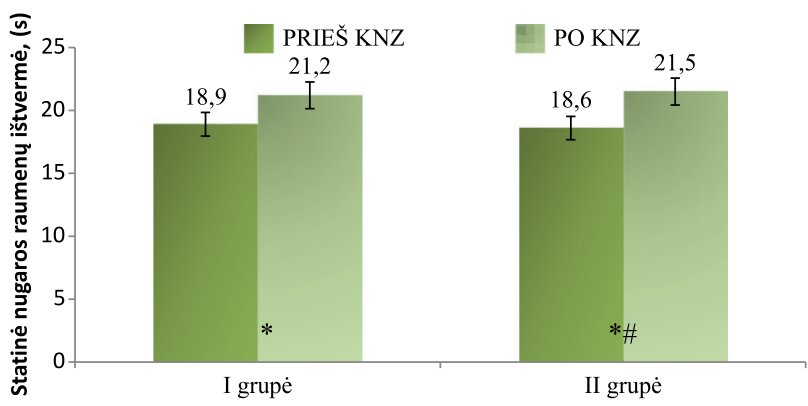

8 pav. I ir II grupių tiriamujų statinès nugaros raumenų jègos ištvermès vertinimas prieš ir po kineziterapijos užsièmimų ciklo

Pastaba: ${ }^{*} \mathrm{p}<0,05$, lyginant grupių rezultatus prieš $\mathrm{KNZ}$ ir po $\mathrm{KNZ}$ užsièmimų, \#p < 0,05, lyginant grupių rezultatus po KNZ užsiëmimų.

ir siekẻ 18,8 $\pm 2,4$ sekundès, šis pokytis buvo statistiškai reikšmingas $(\mathrm{p}=0,023)$. Analizuojant II grupès tiriamuju statinę pilvo raumenų ištvermę, nustatyta, kad prieš kineziterapijos užsiemimų ciklą statinè pilvo raumenų ištvermé siekè 15,6 $\pm 3,3$ sekundès. Antrinio testavimo metu, t. y. po 4 savaičių, taikyto stuburo stabilizavimo ir smūginès bangos terapijos užsièmimų ciklo pilvo raumenų statinė ištvermè pagerèjo ir siekè 19,8 $\pm 3,4$ sekundès, šis pokytis statistiškai reikšmingas $(p=0,014)$. Palyginus abiejų tiriamuju grupių rezultatus po kineziterapijos, nustatyta, kad statinė pilvo raumenų jẻgos ištvermė pagerẻjo abiejų grupių tiriamiesiems, tačiau didesnis pilvo raumenų statinès ištvermès padidejjimas $(p=0,018)$ nustatytas II grupès tiriamiesiems, kuriems taikytas stuburo stabilizavimo ir smūginès bangos terapijos užsièmimų ciklas (7 pav.).

Atlikus I grupès tiriamujų nugaros raumenų statinès jègos ištvermès vertinimą, nustatyta, kad prieš kineziterapiją nugaros raumenų statinè jẻgos ištvermé buvo $18,9 \pm 2,6 \mathrm{se}-$ kundès, o po 4 savaičių stebètas pagerèjimas ir nugaros raumenų statinè jègos ištvermè siekè $21,2 \pm 2,4$ sekundès. II grupès tiriamujų nugaros raumenų statinè jègos ištvermė prieš kineziterapijos užsièmimų ciklą buvo $18,6 \pm 3,4$ sekundės, po 4 savaičiu atlikus pakartotinị ištyrimą nugaros raumenų statinè jẻgos ištvermè siekè $21,5 \pm 3,2$ sekundès. Palyginus abiejų grupių tiriamųjų nugaros raumenų stati- 
nès jègos ištvermès pokyčius, pastebètas teigiamas statistiškai reikšmingas pokytis $(\mathrm{p}<0,05)$. Lyginant grupių rezultatus, nustatytas statistiškai reikšmingai didesnis $(\mathrm{p}=0,001)$ pokytis II grupès tiriamiesiems, kuriems taikytas stuburo stabilizavimo ir smūginès bangos terapijos užsièmimų ciklas (8 pav.).

\section{REZULTATU APTARIMAS}

Šio tyrimo tikslas - išanalizuoti dviejų skirtingų kineziterapijos programų, t. y. stuburo stabilizavimo pratimų programos ir stuburo stabilizavimo pratimų programos ir smūginės bangos terapijos, poveikį radikulopatija sergančių asmenų jaučiamam skausmui, dinaminiam stabilumui ir liemens raumenų statinès jègos ištvermei. Tyrimo rezultatai parodè, kad abi kineziterapijos programos turi teigiamą poveiki radikulopatija sergančių asmenų funkciniams rodikliams ir jų kaitai. Daugelis užsienio autorių nurodo, kad kineziterapija yra vienas iš efektyviausių radikulopatijos gydymo metodų, padedančių sumažinti skausmą ir pagerinti gyvenimo kokybę $[1,14,16]$. Klinikinès nugaros skausmo mažinimo rekomendacijos fizinị aktyvumą ịvardija kaip vieną iš geriausių skausmo mažinimo ir su nugaros skausmu susijusios negalios valdymo priemonių.

2017 m. Akthar su kolegomis savo darbe pateikė išvadą, kad apatinės nugaros dalies skausmas yra vienas iš pagrindinių rodiklių, dèl kurio asmenys kreipiasi ị kineziterapeutą, todèl kineziterapeutas turi nustatyti, kokią kineziterapijos metodiką taikyti, siekiant sumažinti skausmą ir pagerinti funkcinius bei fizinius rodiklius [16]. Sisteminès mokslinių straipsnių apžvalgos aptaria įvairių pratimų poveikị radikulopatijai (McKenzie, Williams pratimu programos, stuburo stabilizavimo pratimu programos ir kt.). Daugelio mokslinių straipsnių išvadose pažymima, kad stuburo stabilizavimo pratimai yra vieni geriausių, nes jie pagerina neuroraumeninę kontrolę, ištvermę ir raumenų jègą, kas lemia geresnị dinaminio stabilumo palaikymą ir jo valdymą $[11,14,16]$, todèl, atlikdami savo tyrimą, pasirinkome stuburo stabilizavimo pratimus. Taip pat vienai iš tiriamujų grupių šalia stuburo stabilizavimo pratimų buvo taikomas smūginès bangos terapijos ciklas. Kaip pažymima $2016 \mathrm{~m}$. Sheveleva ir bendraautorių skelbtoje mokslinejje publikacijoje, smūginès bangos terapijos indikaciju sąrašas nuolat didejja, nes fiksuojamas teigiamas ir veiksmingas poveikis, gydant uždegiminius ir trauminius susirgimus [17].

Remdamiesi atliktais tyrimais ir gautais rezultatais, pastebejjome, kad tiek stuburo stabilizavimo pratimų taikymas, tiek smūginės bangos terapijos taikymas statistiškai reikšmingai sumažina skausmą, pagerina liemens raumenų jẻgos ištvermę, dinaminị stabilumą ir jo valdymą [16, 18]. Mūsų tyrimo rezultatai sutampa su užsienio autorių atliktais tyrimais ir gautais rezultatais. Atlikę tyrimą, nustatėme, kad abiejų grupių tiriamiesiems po 4 savaičių užsiėmimų ciklo statistiškai reikšmingai sumažèjo skausmas, kuris kito nuo vidutinio skausmo stiprumo iki silpno skausmo pojūčio. Lygindami grupes, pastebejjome, kad skausmas statistiškai reikšmingai geriau sumažejo II grupès tiriamiesiems, kuriems taikytas stuburo stabilizavimo ir smūginès bangos terapijos ciklas, lyginant su I grupès tiriamaisiais, kuriems taikyta tik stuburo stabilizavimo pratimų programa. II grupės tiriamiesiems skausmas sumažèjo $52,8 \%$, o I grupès tiriamiesiems - 33,3\%. Taigi galima teigti, kad abi programos turi teigiamą poveiki skausmo mažinimui. Smūginès bangos terapija turi didesnį teigiamą poveikį skausmo mažinimui dèl to, kad šių bangų veikimas skatina angiogenezę, didina perfuziją išeminiuose audiniuose, mažina uždegimo procesą, intensyvina ląstelių diferenciaciją ir keičia skausmo signalo perdavimą [15].

Posturalinė kontrolè apibūdinama kaip kūno padèties palaikymas erdvejje, išlaikant pusiausvyrą ir koordinaciją. Nors kūno padèties valdymas ir palaikymas yra būtini tiek statinėmis, tiek dinaminėmis aplinkos sąlygomis, tačiau dinaminè posturalinè kontrolè turi didesnị vaidmenị kasdieniniame gyvenime. Pagerèjus posturalinei kontrolei, kai taikomas reabilitacinis gydymas, sumažėja skausmas griaučių ir raumenų sistemos sutrikimų atvejais [19]. Užsienio šalių autoriai nurodo, kad apatinès nugaros dalies skausmas sąlygoja sutrikusią posturalinę kontrolę ir jos valdymą [20, 21]. Tą pastebejjome ir mes, atlikę pirminị tiriamujjų dinaminio stabilumo vertinimą ir nustatę kombinuoto rezultato koeficienta, kuris parodè, kad abiejų grupių tiriamiesiems yra padidejusi tikimybė patirti traumas, nes koeficientas nesiekè $94 \%$. Analizuojant duomenis po 4 savaičių trukusio tyrimo, nustatytas visomis kryptimis nustumto atstumo padidejimas, tačiau statistiškai reikšmingi pokyčiai fiksuoti posteromedialinejje ir posterolateralinejje kryptyse. Anteriorinėje kryptyje statistiškai reikšmingų pokyčių nefiksuota, nors stebima nustumto atstumo didejimo tendencija. Tą pati teigia ir Hong su kolegomis, kurie nustatè, kad po kineziterapijos didesni pokyčiai fiksuoti posteromedialineje ir posterolateralinėje kryptyse [21]. Po tyrimo taip pat fiksuotas kombinuoto rezultato koeficiento padidejimas, kuris abiejose tiriamųjų grupėse siekė daugiau nei 94 \%. Lyginant grupes, statistiškai reikšmingo pokyčio nefiksuota, nors geresnè tendencija buvo stebima II grupejje, kuriai kartu su stuburo stabilizavimo pratimais taikyta smūginė bangos terapija. Panaši tendencija pastebėta $2014 \mathrm{~m}$. Lee su kolegomis atliktame tyrime, kur didesni ir statistiškai reikšmingesni dinaminio stabilumo pokyčiai po 6 savaičių kineziterapijos fiksuoti grupejje, kurioje taikyta smūginių bangų terapija, lyginant su kita grupe, kuriai atliktas Williams ir McKenzie pratimų programos ciklas [20].

Taip pat reikia pažymèti, kad statiniam ir dinaminiam darbui atlikti bei tinkamai valdyti kūno pusiausvyrą reikalinga gera statiné pilvo ir nugaros raumenų jẻgos ištvermé. Prieš tyrimą nustatyta pablogèjusi pilvo ir nugaros raumenų statinė jègos ištvermè, kas lèmé pakitusị dinaminị stabilumą ir jo valdymą. Po tyrimo nustatyta, kad abi programos pagerino pilvo ir nugaros raumenų statinę ištvermès jègą. Lyginant grupes, galima teigti, kad II grupès tiriamųjų pilvo ir nugaros raumenų statinė ištvermė buvo statistiškai reikšmingai geresnè nei I grupès tiriamųjų, kuriems taikyta tik stuburo stabilizavimo pratimų programa. 
Taigi, palyginę abiejų kineziterapijos programų poveikị skausmui, dinaminiam stabilumui, raumenų jègos ištvermei, juosmens ir dubens srities stabilumui, esant radikulopatijai, galime teigti, kad abi programos buvo veiksmingos, gerinant minètus rodiklius. Didesnị teigiamą poveikị skausmo mažinimui, dinaminio stabilumo valdymui, raumenų jėgos ištvermei turẻjo stuburo stabilizavimo pratimų programa kartu su smūginès bangos terapijos taikymu.

\section{IŠVADOS}

1. Po kineziterapijos užsiėmimų ciklo sumažejo abiejų grupių tiriamujų jaučiamas skausmas, kuris kito nuo vidutinio ( 5 balų) iki silpno (3 balų). Lyginant grupes, nustatytas statistiškai reikšmingai didesnis skausmo sumažėjimas II grupès tiriamiesiems, kuriems taikytas stuburo stabilizavimo ir smūginès bangos terapijos ciklas.

2. Po kineziterapijos užsièmimų ciklo abiejų grupių tiriamiesiems statistiškai reikšmingai padidèjo pilvo ir nugaros raumenų statinė jègos ištvermè. Didesnis teigiamas pokytis fiksuotas II grupès tiriamiesiems, kuriems taikytas stuburo stabilizavimo pratimų programos ir smūginès bangos terapijos ciklas.

3. Po kineziterapijos užsiėmimų ciklo pagerẻjo tiriamųjų dinaminis stabilumas, padidejo indikatoriaus nustumto atstumo ilgis posterolateraline ir posteromedialine kryptimis, didejo anteriorinės krypties atstumas, tačiau nefiksuoti reikšmingi pokyčiai. Analizuojant kombinuoto rezultato koeficientą, nustatytas statistiškai reikšmingas pagerèjimas abiejų grupių tiriamiesiems, kas sąlygoja sumažèjusią tikimybę patirti traumas.

\section{Literatūra}

1. Airaksinen O, Brox JI, Cedraschi C, Hildebrandt J, KlaberMoffett J, Kovacs F, et al. European guidelines for the management of chronic nonspecifc low back pain. European Journal of Spine 2016; 15(Suppl 2): S192-300. https://doi.org/ 10.1007/s00586-006-1072-1

2. Andersson G. Epidemiologic features of chronic low-back pain. Lancet 2009; 354: 581-5. https://doi.org/10.1016/ S0140-6736(99)01312-4

3. Hekmatfard M, Sanjari MA, Maroufi N, Saeedi H, Ebrahimi E, Behtash $\mathrm{H}$. A preliminary study of the objective measurement of compliance rates for semirigid lumbar-support use in patients with chronic nonspecific low back pain: how important is the compliance rate? Asian Journal of Spine 2017; 11(5): 748-55. https://doi.org/10.4184/asj.2017.11.5.748

4. Goossens N, Rummens S, Janssens L, Caeyenberghs K, Brumagne $\mathrm{S}$. Association between sensorimotor impairments and functional brain changes in patients with low back pain: a critical review. Am J Phys Med Rehabil 2018; 97(3): 200-11. https://doi.org/10.1097/PHM.0000000000000859

5. Eshraghi Y, Desai V, Cajigal Cajigal C, Tabbaa K. Outcome of percutaneous lumbar synovial cyst rupture in patients with lumbar radiculopathy. Pain Physician 2016; 19(7): E1019-25.

6. Schoenfeld AJ, Laughlin M, Bader JO, Bono CM. Characterization of the incidence and risk factors for the development of lumbar radiculopathy. J Spinal Disord Tech 2012; 25(3): 163-7. https://doi.org/10.1097/ BSD.0b013e3182146e55

7. Kresal F, Suklan J, Roblek V, Jerman A, Meško M. Psychosocial risk factors for low back pain and absenteeism among Slovenian professional drivers. Cent Eur J Public Health 2017; 25(2): 135-40. https://doi.org/10.21101/cejph.a4385

8. DeFroda SF, Daniels AH, Deren ME. Differentiating radiculopathy from lower extremity arthropathy. The American Journal Medicine 2016; 129(10): 1124-7. https://doi.org/10.1016/j.amjmed.2016.06.019

9. Min JH, Choi HS, Ihl Rhee W, Lee JI. Association between radiculopathy and lumbar multifidus atrophy in magnetic resonance imaging. Journal of Back Musculoskelet Rehabil 2013; 26(2): 175-81. https://doi.org/10.3233/BMR-130365

10. Hüllemann P, von der Brelie C, Manthey G, Düsterhöft J, Helmers AK, Synowitz M, et al. Educed laser-evoked potential habituation detects abnormal central pain processing in painful radiculopathy patients. European Journal of Pain 2017; 21(5): 918-26. https://doi.org/10.1002/ejp.994

11. Bosković K, Todorović-Tomasević S, Naumović N, Grajić M, Knezević A. The quality of life of lumbar radiculopathy patients under conservative treatment. Vojnosanit Pregl 2016; 66: 807-12. https://doi.org/10.2298/ VSP0910807B

12. Turner I, Choi D. Cervical disc arthroplasty improves quality of life in cervical radiculopathy and myelopathy: a 2-yr follow-up. Neurosurgery 2017; 89(1): 111-3. https://doi.org/ 10.1093/neuros/nyx424

13. Kjaer P, Kongsted A, Hartvigsen J, Isenberg-Jørgensen A. National clinical guidelines for non-surgical treatment of patients with recent onset neck pain or cervical radiculopathy. European Journal of Spine 2017; 15(1): 22-9. https://doi.org/ 10.1007/s00586-017-5121-8

14. Boucher JA, Preuss R, Henry SM, Dumas JP, Larivière C. The effects of an 8-week stabilization exercise program on lumbar movement sense in patients with low back pain. BMC Musculoskelet Disord 2016; 17: 23. https://doi.org/10.1186/ s12891-016-0875-4

15. Liang HW, Wang TG, Chen WS, Hou SM. Thinner plantar fascia predicts decreased pain after extracorporeal shock wave therapy. Clin Orthop Relat Res 2017; 460: 219-25.

16. Akhtar MW, Karimi H, Gilani SA. Effectiveness of core stabilization exercises and routine exercise therapy in management of pain in chronic non-specific low back pain: A randomized controlled clinical trial. Pak J Med Sci 2017; 33(4): 1002-6. https://doi.org/10.12669/pjms.334.12664

17. Sheveleva N, Minbayeva L, Belyayeva Y. Shock wave therapy application in clinical practice (review). Georgian Med News 2016; 22(52): 42-7.

18. Andersen MØ, Andresen AK, Lorenzen MD, IsenbergJørgensen A, Støtterup C. Non-surgical treatment of lumbar radiculopathy. Ugeskr Laeger 2017; 179(23).

19. Yoon SH, Shin MK, Choi EJ, Kang HJ. Effective site for the application of extracorporeal shock-wave therapy on spasticity in chronic stroke: muscle belly or myotendinous junction. Annual of Rehabilitation Medicine 2017; 41(4): 547-55. https://doi.org/10.5535/arm.2017.41.4.547

20. Lee JC, Lee SH, Peters C, Riew KD. Adjacent segment pathology requiring reoperation after anterior cervical 
arthrodesis: the influence of smoking, sex, and number of operated levels. Spine Phila Pa 2015; 40(10): 571-7. https://doi.org/10.1097/BRS.0000000000000846

21. Hong JO, Park JS, Jeon DG, Yoon WH, Park JH. Extracorporeal shock wave therapy versus trigger point injection in the treatment of myofascial pain syndrome in the quadratus lumborum. Annual of Rehabilitation Medicine 2017; 41(4): 582-8. https://doi.org/10.5535/arm.2017.41.4.582

\section{J. Bubelis}

\section{THE EFFECT OF CORE STABILIZATION EXERCISES AND SHOCK WAVE THERAPY IN PATIENTS WITH RADICULOPATHY}

\section{Summary \\ Background. Radiculopathy is a damage to the nerve root of the lumbar spine, which develops due to nerve root pressure and irri- tation. Lumbar radiculopathy is characterized by a wide variety of symptoms including the most common: lower back pain and lower limb pain, muscle weakness, disorders of proprioreceptive and postural control, which adversely affect the daily activities and quality of life of a person and result in a decrease in labour productivity in the working age population as well as disability development. Physical exercises and physiotherapy used during physical therapy have shown to reduce pain, improve and man- age balance.}

Materials and methods. The study involved 40 subjects ( 22 women and $18 \mathrm{men}$ ) diagnosed with lumbar radiculopathy. The subjects were randomly divided into two groups of 20 subjects in each group; Group I had a cycle of spinal stabilization exercises, and Group II had a cycle of spinal stabilization exercises and shockwave therapy sessions. Visual Analogue Scale (VAS) was selected for pain assessment; for the dynamic stability assessment, the modified Star Excursion Balance Test was selected; and for the evaluation of trunk muscle static strength endurance two tests were chosen: abdominal muscle static strength endurance test and back muscle static strength endurance test. The data were processed by mathematical statistical analysis.

Results. The severity of pain after the use of different physiotherapy programs decreased in both groups. In Group I, the pain decreased from $5.77 \pm 1.88$ points to $3.85 \pm 1.25$ points (the change in pain intensity was $1.92 \pm 0.19$ points); in Group II, the pain decreased from $5.40 \pm 1.24$ points to $2.55 \pm 1.05$ points (pain intensity change $-2.85 \pm 0.63$ points). By assessing the changes in dynamic stability of subjects after 4 weeks, the physiotherapy sessions showed an improvement in the dynamics of stability in both groups, but greater changes were recorded in Group II subjects with a cycle of spinal stabilization and shockwave therapy. Also, before and after the cycle of physiotherapy, the coefficient of the combined result was calculated which indicated whether there was a possibility of injury due to deterioration of dynamism stability and its management. Before the cycle of physiotherapy, the combined result in Group I was $92.3 \%$ and in Group II it was $92.9 \%$. After 4 weeks of applied physiotherapy, the combined result coefficient increased in both groups: in Group I it increased by $2.8 \%$ and in Group II by $3.5 \%$. After the cycle of physiotherapy, the combined result in Group I was $95.1 \%$, while in Group II it was $96.4 \%$. It is estimated that if the combined result is less than $94 \%$, there is an increased probability of traumas. Thus, before the cycle of physiotherapy, individuals with radiculopathy and experiencing moderate pain are more likely to experience lower limb traumas due to dynamic changes in stability. After the cycle of exercises, we see that the combined result has reached more than $94 \%$ and it indicates that the probability of suffering injuries has decreased $(\mathrm{p}=0.032)$. Also, after physiotherapy, an improvement in abdominal and back muscle static strength endurance was observed, which improved in both groups of subjects, however the improved trunk muscle static strength endurance $(p=0.029)$ was fixed in Group II subjects who used spinal stabilization and shock wave therapy cycle.

Conclusions. 1. After the cycle of physiotherapy, the pain experienced by the two groups decreased from baseline (from 5 to 6 points) to weak ( 3 to 2 points) pain. When comparing two groups, a greater reduction in pain was observed in Group II subjects with a spinal stabilization and shock wave therapy cycle. 2. After the cycle of physiotherapy classes, the subjects of both groups increased abdominal and spinal muscular static strength endurance. Greater positive change was fixed in Group II subjects. 3. After the cycle of physiotherapy sessions, the dynamic stability of the subjects improved and the chance of injury was reduced. 4. Comparison between the two groups suggests that the cycle of application of spinal stabilization exercise program and shock wave therapy has a greater positive effect on pain, muscle endurance, dynamic stability and its management.

Keywords: lumbar radiculopathy, spinal stabilization exercises, shock wave therapy, pain.

Gauta:

20180319

Priimta spaudai: 20180522 